\title{
Optimasi Google Suites dan PowerPoint untuk Membuat Bahan Ajar Kreatif pada Mata Pelajaran PAI
}

\author{
Unik Hanifah Salsabila ${ }^{1}$, Anggi Pratiwi ${ }^{2}$ \\ ${ }^{1}$ Departemen Pendidikan Agama Islam, Fakultas Agama Islam Universitas Ahmad Dahlan Yogyakarta, \\ Jl. Kapas No.9, Daerah Istimewa Yogyakarta, 55166, Indonesia \\ ${ }^{2}$ Departemen Pendidikan Guru Madrasah Ibtidaiyah, Fakultas IImu Tarbiyah dan Keguruan, Universitas Islam Negeri Sunan \\ Kalijaga Yogyakarta, Jl. Ring Road Selatan, Tamanan, Banguntapan, Bantul, Yogyakarta, 55191, Indonesia
}

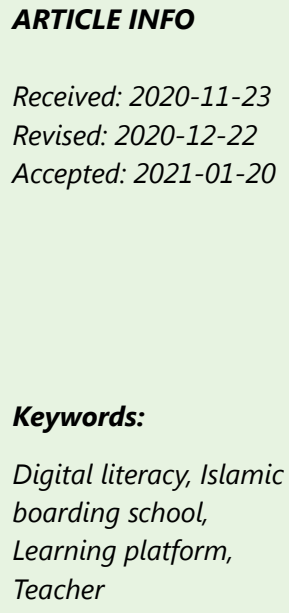

Received: $2020-11-23$ Revised: 2020-12-22 Accepted: 2021-01-20

\section{Keywords:}

Digital literacy, Islamic boarding school, Learning platform, Teacher

\section{ABSTRACT}

The training program aims to increase knowledge of digital literacy. It improves skills in the use of digital platforms, especially Google Suites in Islamic Education learning, and increase creativity in making PAl subjects using PowerPoint software for Islamic interns in Yogyakarta City. Several planned activities in implementing the digital platform optimization program for Islamic Education teachers in Islamic boarding schools proposed to address these different problems, namely as follows: socialization of digital literacy requires content. Then Google Suites and PowerPoint optimization training for Islamic Education learning. Training lasts four days, with a total meeting length of approximately 700-800 minutes for each session. The participants were 12 PAl teachers from several Islamic boarding schools in Yogyakarta who randomly chosen. Training begins at Even Semester and the Odd Semester. Several presenters are involved in the training, namely one digital media specialist, two lecturers on educational technology, and two students. The outcomes to be achieved from this training program are: increasing the knowledge and understanding of teachers about the needs of digital literacy. Then enhance the abilities of teachers to use the Google Suites tool. Last, increasing the creativity of teachers to build teaching materials using PowerPoint.

(C) 2021 Published by University of Merdeka Malang This is an open access article distributed under the CC BY-SA 4.0 license

(https://creativecommons.org/licenses/by-sa/4.0/)

How to cite: Salsabila, U.H. \& Pratiwi, A. (2021). Optimasi Google Suites dan Powerpoint untuk Membuat Bahan Ajar Kreatif pada Mata Pelajaran PAI. Abdimas: Jurnal Pengabdian Masyarakat Universitas Merdeka Malang, 6(1), 1-9. https://doi.org/10.26905/abdimas.v6i1.5060

\section{PENDAHULUAN}

Kota Yogyakarta dikenal dengan sebutan kota pelajar karena banyaknya sekolah dan perguruan tinggi. Tetapi tidak banyak diketahui orang bahwa bukan hanya sekolah dan perguruan tinggi saja yang menjamur di kota ini, melainkan juga pondok pesantren. Setiap pesantren memiliki ratusan hingga ribuan santri, baik yang masih berada di tingkatan sekolah maupun perguruan tinggi (Mahmudi, 2009). Dari 
ABDIMAS: Jurnal Pengabdian Masyarakat Universitas Merdeka Malang Volume 6, No 1, February 2021: 1-9

tahun ke tahun, jumlah pondok pesantren di Yogyakarta terus bertambah. Hal ini dikarenakan banyaknya santri pondok pesantren yang setelah menyelesaikan studinya lantas merintis pondok pesantren baru.

Pada era modern, sistem pendidikan di lingkungan pondok pesantren tidak lagi terfokus pada sistem tradisional dengan meniadakan mata pelajaran umum dan hanya mempelajari kitab kuning melalui kelompok-kelompok kajian. Belakangan, pondok pesantren cenderung mampu beradaptasi dengan kemajuan zaman sehingga turut mengupayakan pelayanan pendidikan dan bimbingan UndangUndang No. 14 Tahun 2005 Tentang Guru dan Dosen selama 24 jam dan menggabungkan kurikulum pendidikan akademis sekolah dengan kurikulum pondok pesantren. Modernisasi tersebut dilakukan tanpa menghilangkan karakteristik khas kepesantrenan yang menjadikan prinsip keteladanan terhadap guru sebagai figur panutan selama menjalani masa pendidikan.

Menindaklanjuti realita tersebut maka tentunya profesionalitas seorang guru menempati peran penting dalam menginternalisasikan nilai dalam proses belajar mengajar (Yazdi, 2012), khususnya untuk pembelajaran PAI. Undang-Undang Nomor 14 Tahun 2005 tentang guru dan dosen, menyebutkan bahwa salah satu tuntutan kompetensi yang harus dimiliki guru adalah pemanfaatan sarana TIK untuk berinteraksi dengan peserta didik dan juga sebagai media pengembangan diri demi ketercapaian penguasaan kompetensi belajar peserta didik di ruang kelas (Undang-Undang No. 14 Tahun 2005 Tentang Guru dan Dosen). Mengemban amanah pendidikan dan berperan sebagai menjadi figur keteladanan sekaligus tentu tidak mudah bagi seorang guru. Terlebih ketika materi pelajaran yang harus disampaikan merupakan konten normatif yang terkesan membosankan bagi peserta didik (Salsabila et al., 2020). Oleh karena itu, diperlukan adanya kompetensi individu yang memudahkan terjadinya inovasi-inovasi berkala di dalam pembelajaran (Rushton et al., 2009).

Berdasarkan observasi dan interaksi yang dilakukan antara pihak mitra dengan pengusul, ditemukan bahwa masih banyak guru PAI di lingkungan pondok pesantren yang merasa kesulitan untuk mengoptimalkan ketersediaan platform digital sebagai media ajar di ruang kelas. Kondisi tersebut tentu menyulitkan pengembangan inovasi belajar yang semestinya dilakukan secara berkala oleh guru. Dalam konteks ini, peserta didik jadi cenderung merasa bosan untuk mempelajari materi yang disampaikan. Bahkan masih banyak guru pondok pesantren yang berasumsi bahwa satu-satunya media internalisasi nilai dan penyampaian materi ajar yang paling ideal adalah melalui metode ceramah (Rikawati \& Sitinjak, 2020). Padahal sudah banyak termuan yang menyebutkan bahwa pengembangan visualisasi melalui media, seperti slide presentasi (Nurjanah, 2020), gamifikasi (Jusuf, 2016), RENSTRA Universitas Ahmad Dahlan (Tim Dosen UAD, 2019), dan lain sebagainya dapat mempermudah internalisasi nilai dan meningkatkan keterserapan materi. Minimnya kesadaran terkait literasi digital dan kurangnya keterampilan terkait pendayagunaan dan pengembangan media ajar melalui platform digital itulah yang kemudian dikeluhkan mitra kepada pengusul untuk ditindaklanjuti secara berkelanjutan melalui program pelatihan (Salsabila, 2019).

Berdasarkan pada analisis situasi tersebut, maka program optimasi platform pembelajaran menjadi salah satu faktor krusial yang harus segera diselesaikan sehingga kebutuhan belajar peserta didik dapat segera terpenuhi. Terlebih ketika ruang pendidikan dihadapkan pada situasi fluktuatif akibat laju teknologi dari waktu ke waktu. Keterlambatan guru dalam mengejar kompetensi akan menjadi unsur 
penghambat internal dalam menginternalisasikan nilai-nilai pendidikan Islam. Oleh karena itu, pengusul mengualifikasikan permasalahan yang dihadapi mitra adalah sebagai berikut; kurangnya kesadaran guru PAI terhadap kebutuhan literasi digital, lemahnya kompetensi guru PAI dalam mengoptimasi platform digital, dan minimnya kreativitas guru PAI dalam mengembangkan media ajar.

Adapun solusi yang ditawarkan pengusul program adalah sebagai berikut; memberikan sosialisasi mengenai pentingnya literasi digital bagi peserta didik di dalam proses pembelajaran, memberikan pelatihan dan pendampingan optimasi pembelajaran digital online, khususnya menggunakan platform Google Suites, dan memberikan bimbingan teknis penguasaan strategi pembuatan media kreatif dalam pembelajaran dengan menggunakan software PowerPoint. Mengacu pada permasalahan yang dihadapi mitra, maka dilakukan empat pendekatan dalam pelaksanaan program, yakni: (1) perencanaan, meliputi pemetaan sarana dan prasana pendukung yang dimiliki mitra, khususnya ketersedian waktu dan kesiapan guru untuk mengikuti pelatihan secara konsisten; (2) pengorganisasian, meliputi kerjasama terstruktur antara tim pelaksana dengan mitra; (3) proses, meliputi teknis pelaksanaan kegiatan pelatihan yang mengarah pada pencapaian target; dan (4) evaluasi, meliputi pengukuran keterlaksanaan program, ketercapaian target, fokus pembinaan, dan rencana pendampingan sebagai keberlanjutan dari pelaksanaan program.

Adapun tujuan dari pelaksanaan program adalah sebagaimana berikut; meningkatnya kesadaran guru PAI terhadap kebutuhan literasi digital, meningkatnya keterampilan guru PAI dalam memanfaatkan Google Suites, dan meningkatnya kreativitas guru PAI dalam membuat bahan ajar menggunakan software PowerPoint. Usulan solusi penyelesaian permasalahan mitra memiliki kesesuaian dengan rancangan peta jalan PPM UAD. Disebutkan bahwa dalam jangka pendek, yakni kisaran tahun 2020 sampai 2045 RENSTRA Universitas Ahmad Dahlan, lembaga internal PPM UAD berupaya memfokuskan pelaksanaan kegiatan pengabdian masyarakat agar mengarah pada akselerasi wilayah marginal menuju kawasan yang cerdas, sehat, dan ramah lingkungan disertai dengan pengembangan karakter sosio-ecopreneur disertai keunggulan nilai universal keislaman (Tim Dosen UAD, 2020). Merujuk pada konten tersebut maka program pelatihan optimasi digital untuk guru PAI di pondok pesantren menjadi bagian positif dari realisasi rancangan pengembangan kawasan cerdas dan berkarakter nilai keIslaman, khususnya di dalam bidang pendidikan.

\section{METODE}

Memperhatikan luaran atau hasil kegiatan yang ingin dicapai, maka metode yang akan digunakan untuk mengatasi permasalahan dapat digolongkan menjadi dua tahap, yaitu data potensi pengembangan wawasan literasi digital guru-guru PAI dalam program pemberdayaan masyarakat. Untuk mencapai target luaran tersebut maka dilakukan metode seperti berikut: (1) Sosialisasi program melalui pertemuan berkala antara pendamping dengan kelompok sasaran; (2) Penyelenggaraan pelatihan penggunaan Google Suites dan pembuatan bahan ajar kreatif melalui software PowerPoint; dan (3) Evaluasi program melalui pre-test dan post-test. Model evaluasi ketercapaian luaran menggunakan Model Kirkpatrick pada Panduan Pengabdian kepada Masyarakat (PPM) Universitas Ahmad Dahlan sebagaimana tertuang pada Gambar 1 (Panchenko, 2013). 
ABDIMAS: Jurnal Pengabdian Masyarakat Universitas Merdeka Malang Volume 6, No 1, February 2021: 1-9

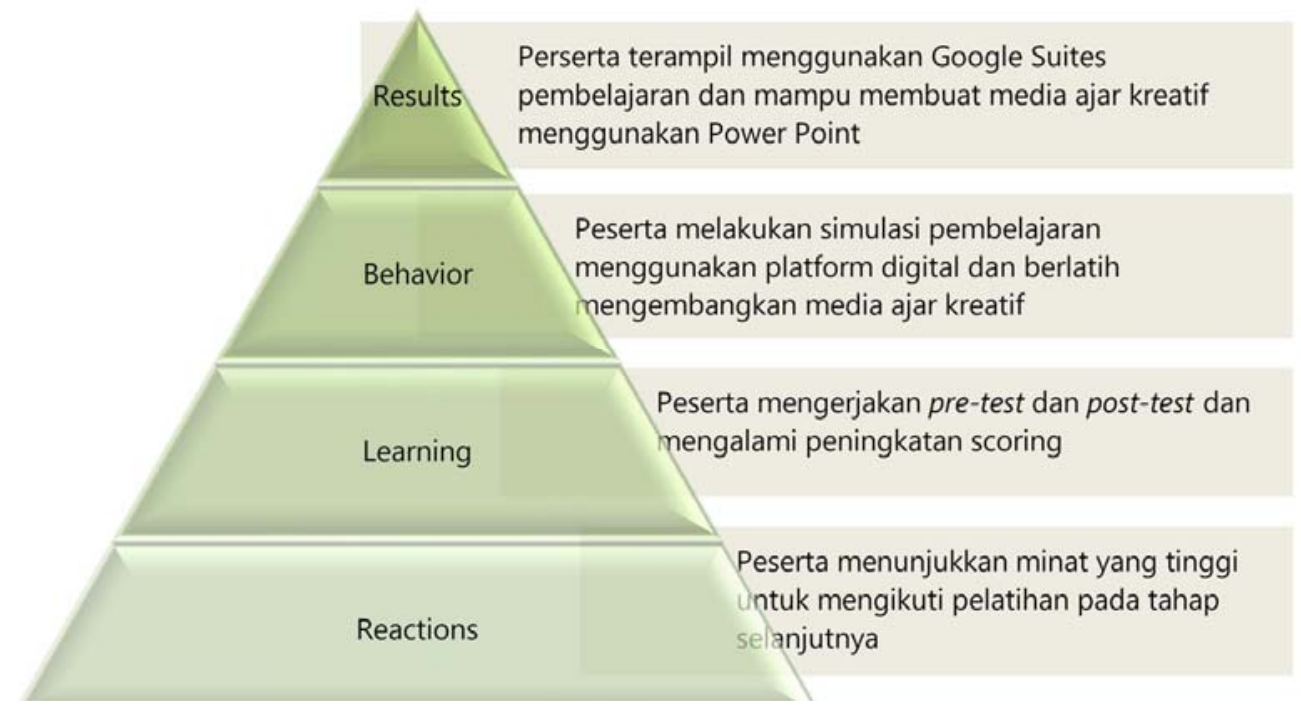

Gambar 1. Rencana evaluasi dan luaran program

Secara garis besar, teknis pelaksanaan program dibagi menjadi empat sesi yang saling berkelanjutan. Sesi pertama dan kedua dilaksanakan pada Semester Ganjil Tahun Pelajaran 2019/2020 melalui forum tatap muka dengan durasi sekitar 700-800 menit atau 13 jam dari pukul 08:00 sampai 15:00 WIB. Sedangkan sesi ketiga dan keempat dilaksanakan melalui forum tatap muka pada Semester Genap Tahun Pelajaran 2020/2021 dengan durasi yang sama dengan sesi pertama dan kedua (Tim Dosen UAD, 2020). Peserta program terdiri dari 12 orang guru PAI dari lingkungan pondok pesantren di Yogyakarta yang terpilih secara acak melalui form pendaftaran online yang disebarluaskan oleh pengusul. Pelatihan sesi pertama dan kedua dilaksanakan pada tanggal 07-08 Juli 2020, sedangkan sesi ketiga dan keempat dilaksanakan tanggal 22 sampai 23 September 2020. Detail rundown kegiatan pelatihan tertuang secara terperinci di dalam Tabel 1.

Tabel 1. Rundown kegiatan pelatihan

\begin{tabular}{|c|c|c|c|}
\hline Sesi & Materi Kegiatan & Waktu & Pemateri \\
\hline 1 & $\begin{array}{l}\text { Pre-test optimasi digital } \\
\text { Workshop Sosialisasi Literasi Digital Peserta Didik }\end{array}$ & $\begin{array}{l}\text { Selasa, } 7 \text { Juli } 2020 \text { pukul } \\
\text { 08:00-15:00 WIB }\end{array}$ & $\begin{array}{l}\text { Arif Ardy Wibowo, } \\
\text { S.Sn., M.Sn. }\end{array}$ \\
\hline 2 & $\begin{array}{l}\text { Pelatihan Pengenalan Fitur Google Suites untuk } \\
\text { Pembelajaran }\end{array}$ & $\begin{array}{l}\text { Selasa, } 8 \text { Juli } 2020 \text { pukul } \\
\text { 08:00-15:00 WIB }\end{array}$ & Anggi Pratiwi, S.Pd. \\
\hline 3 & $\begin{array}{l}\text { Pendampingan Praktik Penggunaan Fitur Google } \\
\text { Suites untuk Pembelajaran }\end{array}$ & $\begin{array}{l}\text { Selasa, } 22 \text { September } 2020 \\
\text { pukul } \\
\text { 08:00-15:00 WIB }\end{array}$ & $\begin{array}{l}\text { Tim Pengusul dan } \\
\text { Mahasiswa }\end{array}$ \\
\hline 4 & $\begin{array}{l}\text { Post-test optimasi digital } \\
\text { Pelatihan Pembuatan Slide Pembelajaran Kreatif } \\
\text { Menggunakan PowerPoint }\end{array}$ & $\begin{array}{l}\text { Rabu, } 23 \text { September } 2020 \\
\text { pukul } \\
\text { 08:00-15:00 WIB }\end{array}$ & $\begin{array}{l}\text { Unik Hanifah Salsabi- } \\
\text { la, S.Pd.I., M.Pd. }\end{array}$ \\
\hline
\end{tabular}




\section{HASIL DAN PEMBAHASAN}

\section{Hasil pelaksanaan program}

\section{Workshop sosialisasi literasi digital peserta didik}

Kegiatan sosialisasi literasi digital dilaksanakan pada Hari Selasa tanggal 7 Juli 2020 berlokasi di pendopo Den Nanny. Sosialisasi ini berisi materi tentang urgensi pemenuhan kebutuhan literasi digital bagi peserta didik. Workshop sosialisasi diikuti oleh 12 orang guru PAI dari enam pondok pesantren yang dipilih secara acak melalui sebaran form pendaftaran, yakni Ponpes Nurul Ummah, Fauzul Muslimin Islamic Boarding School, Pondok Pesantren Al-Luqmaniyah Assalafiyah, Kotagede Hidayatul Mubtadiien Islamic Boarding, Pondok Pesantren Jamilurrahman As-Salafy, dan Ponpes Al-Ishlah Yogyakarta sebagaimana tampak pada Gambar 3. Pemateri adalah tim dosen pengusul, yakni Arif Ardy Wibowo, S.Sn., M.Sn. yang merupakan akademisi sekaligus praktisi bidang teknologi dan media digital. Pada sesi ini juga dilakukan pre-test terhadap potensi wawasan literasi digital, khususnya optimasi fitur. Hingga akhir acara peserta terlihat antusias menyimak setiap materi dan berkomitmen untuk mengikuti sesi pelatihan pada tahap selanjutnya hingga program selesai.
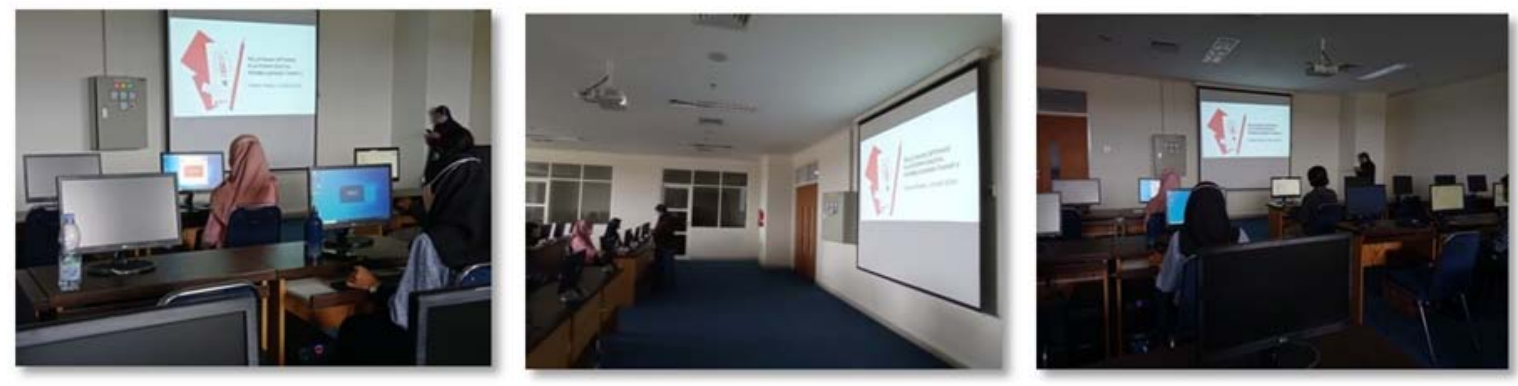

Gambar 2. Workshop sosialisasi kebutuhan literasi digital

\section{Pelatihan pengenalan fitur Google Suites untuk pembelajaran}

Pelatihan penggunaan Google Suites dilaksanakan di laboratorium Fakultas Agama Islam Kampus 4 UAD dengan tetap menjaga protokol, yakni memakai masker dan duduk berjarak antar peserta pelatihan. Pelatihan dilaksanakan pada Hari Rabu tanggal 8 Juli 2020 dari pukul 08:00 sampai 15:00 WIB. Pelatihan diikuti oleh 12 orang guru PAI yang merupakan peserta lanjutan dari workshop sosialisasi sesi pertama. Pada pelatihan kali ini peserta diperkenalkan dengan fitur online Google Suites. Peserta mulai belajar mengenali fitur-fitur umum dari platform Google Suites, seperti Google Drive, Google Document, Google Silde, dan lain sebagainya. Pemateri pada sesi ini adalah seorang praktisi media digital, Anggi Pratiwi, S.Pd. dengan dipandu oleh Yazida Ichsan, S.Pd.I., M.Pd. untuk pendampingan peserta.
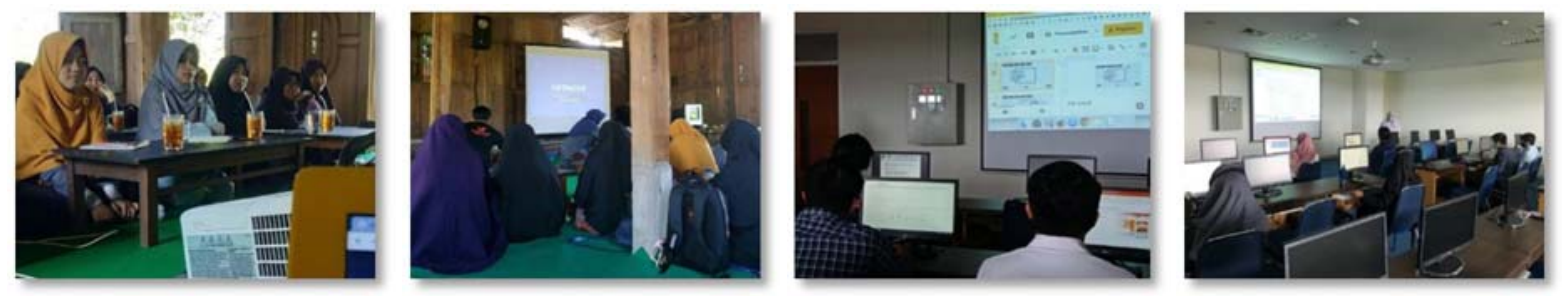

Gambar 3. Pelatihan pemanfaatan Google Suites untuk pembelajaran

Gambar 4. Praktik pembuatan media ajar menggunakan Google Suites 
ABDIMAS: Jurnal Pengabdian Masyarakat Universitas Merdeka Malang Volume 6, No 1, February 2021: 1-9

\section{Pendampingan praktik penggunaan fitur Google Suites untuk pembelajaran}

Pendampingan praktik untuk menggunakan fitur-fitur yang tersedia di dalam aplikasi Google Suites dalam pembelajaran PAI dilakukan pada Semester Genap Tahun Ajaran 2020/2021 Hari Selasa, 22 September 2020 di pendopo Rusunawa Projotamansari Tamanan. Pemateri yang menjadi narasumber utama dalam pelatihan kali ini adalah tim dosen pengusul dengan dibantu oleh beberapa mahasiswa yang terlibat dalam program. Peserta berasal dari komunitas guru PAI pondok pesantren yang sebelumnya telahmengikuti sesi pertama dan sesi kedua pelatihan pada Semester Ganjil Tahun Ajaran 2019/2020. Pada sesi ini, setiap peserta mendapatkan pendampingan privat untuk membuat bahan ajar dengan menggunakan perangkat Google Suites. Selesai mengikuti sesi ini, semua peserta berhasil memiliki minimal satu buah produk bahan ajar dengan menggunakan platform digital online yang ada di Google Suites sekaligus mampu mempraktikkan simulasi penggunaannya untuk pembelajaran PAI.

\section{Pelatihan pembuatan slide pembelajaran kreatif menggunakan powerpoint}

Sesi ini merupakan tahap terakhir dari program optimasi platform digital. Pada sesi ini, peserta belajar tentang bagaimana cara membuat slide kreatif untuk keperluan pembelajaran PAI menggunakan software bawaan Microsoft Office, yakni PowerPoint. Pemateri pada sesi ini adalah Unik Hanifah Salsabila, S.Pd.I., M.Pd. Peserta didampingi oleh tim pengusul serta beberapa mahasiswa yang terlibat untuk praktik membuat slide kreatif sekaligus mensimulasikannya dalam pembelajaran. Pelatihan dilaksanakan pada Hari Rabu, 23 September 2020 pukul 08:00 sampai 15:00 WIB di laboratorium terpadu FAI UAD. Pelatihan dihadiri oleh 12 orang guru PAI dari pondok pesantren yang telah berkomitmen untuk mengikuti pelatihan dari awal hingga akhir program. Akhir sesi dalam pelatihan ini menghasilkan produk berupa pembelajaran kreatif untuk satu materi di dalam Pendidikan Agama Islam dengan menggunakan software PowerPoint. Pada sesi terakhir juga dilakukan post-test optimasi digital.
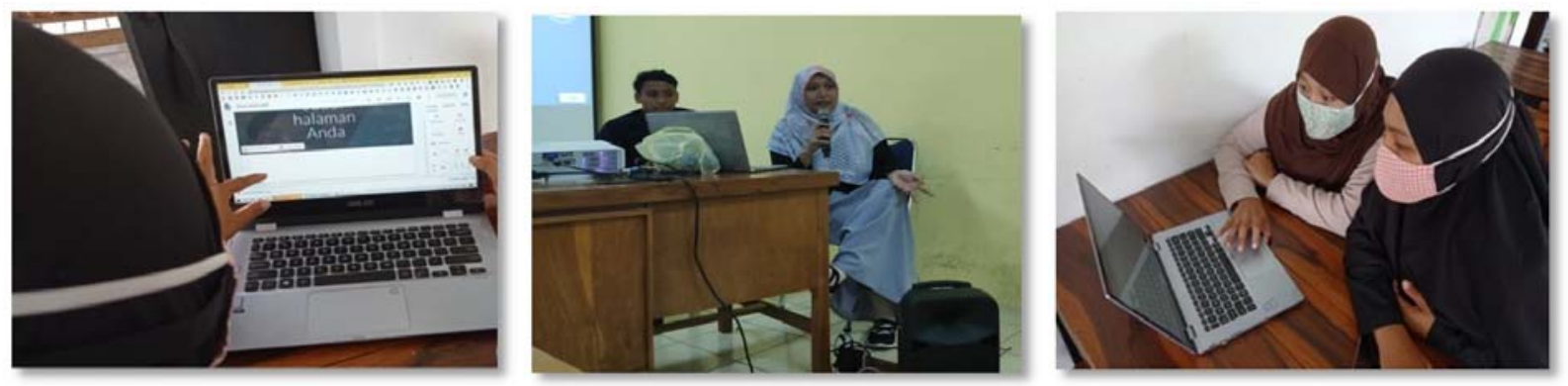

Gambar 5. Pelatihan pembuatan slide kreatif menggunakan PowerPoint

\section{Pembahasan}

Berdasarkan observasi dan pendampingan yang dilakukan oleh tim pengusul terhadap mitra peserta program, diketahui bahwa 12 guru PAI yang telah mengikuti program pelatihan optimasi platform digital telah mengimplementasikan lebih lanjut input wawasan dan keterampilan yang diperoleh selama pelatihan ke dalam kegiatan pembelajaran PAI di lingkungan pondok pesantren masing-masing. 
Sejumlah 12 orang guru PAI tersebut telah berupaya mengembangkan media belajar kreatif sesuai hasil pelatihan ketika mengajar secara online selama kebijakan Study from Home (SFH) atau Belajar Dari Rumah (BDR) diberlakukan pada masa pandemik. Tahap berikutnya yang direncanakan oleh tim pengabdian bersama mitra adalah program kegiatan peningkatan kompetensi keterampilan optimasi platform digital yang lebih luas kepada guru non-PAI, sehingga peningkatan kemampuan optimasi digital di lingkungan ponpes menjadi semakin merata. Dampak pelaksanaan program yang didapatkan oleh peserta pelatihan adalah sebagaimana tertuang pada Tabel 2.

Tabel 2. Dampak pelaksanaan program pelatihan

\begin{tabular}{|c|c|}
\hline Detail Kegiatan & Dampak Bagi Peserta \\
\hline $\begin{array}{l}\text { Pre-test literasi digital } \\
\text { Workshop Sosialisasi Literasi Digital } \\
\text { Peserta Didik }\end{array}$ & $\begin{array}{l}\text { Pendataan potensi wawasan literasi digital guru PAI di pondok } \\
\text { pesantren } \\
\text { Antusiasme dan komitmen peserta untuk mengikuti sesi pelatihan } \\
\text { berikutnya }\end{array}$ \\
\hline $\begin{array}{l}\text { Pelatihan Pengenalan Fitur Google Suites } \\
\text { untuk Pembelajaran }\end{array}$ & $\begin{array}{l}\text { Peningkatan wawasan peserta terhadap fitur yang tersedia di } \\
\text { dalam perangkat Google Suites untuk mengembangkan pembela- } \\
\text { jaran }\end{array}$ \\
\hline $\begin{array}{l}\text { Pendampingan Praktik Penggunaan Fitur } \\
\text { Google Suites untuk Pembelajaran }\end{array}$ & $\begin{array}{l}\text { Peningkatan keterampilan peserta dalam mengoptimasi platform } \\
\text { Google Suites untuk pembelajaran } \\
\text { Setiap peserta menghasilkan satu produk ajar menggunakan fitur } \\
\text { Google Suites dan mensimulasikan penggunaannya. }\end{array}$ \\
\hline $\begin{array}{l}\text { Post-test literasi digital } \\
\text { Pelatihan Pembuatan Slide Pembelajaran } \\
\text { Kreatif Menggunakan PowerPoint }\end{array}$ & $\begin{array}{l}\text { Peningkatan keterampilan peserta dalam mengkreasikan slide } \\
\text { pembelajaran PAI menggunakan PowerPoint } \\
\text { Setiap peserta menghasilkan satu slide kreatif berisi materi pem- } \\
\text { belajaran PAI menggunakan fitur PowerPoint dan mensimulasikan } \\
\text { penggunaannya } \\
\text { Peningkatan wawasan peserta terhadap kebutuhan dan pengem- } \\
\text { bangan literasi digital bagi peserta didik }\end{array}$ \\
\hline
\end{tabular}
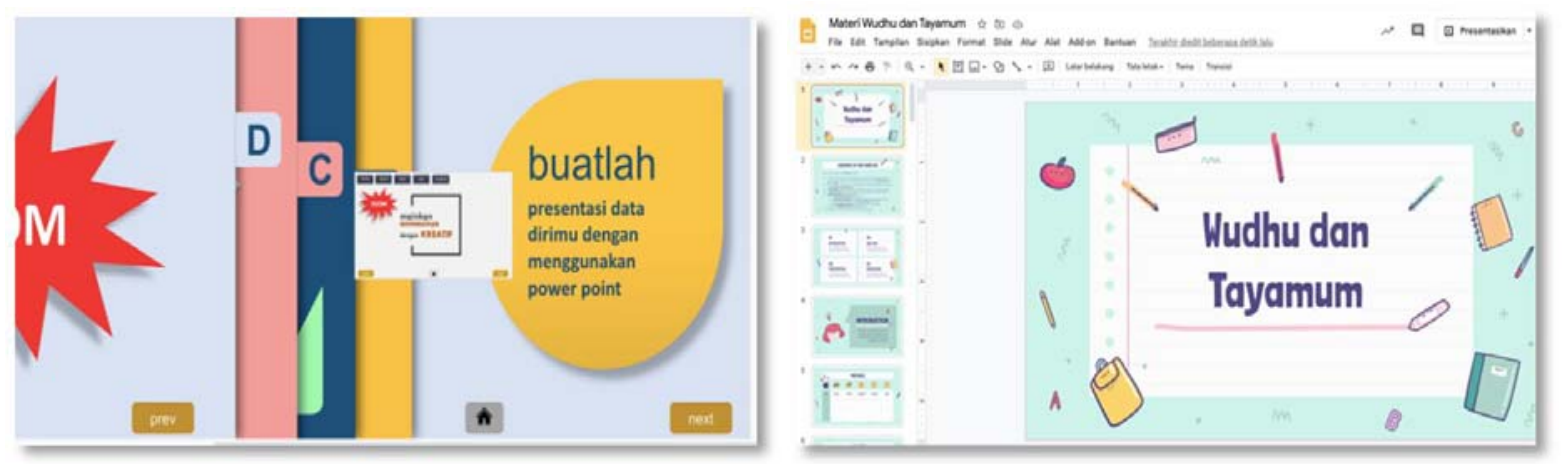

Gambar 6. Beberapa contoh produk bahan ajar yang dihasilkan peserta 
ABDIMAS: Jurnal Pengabdian Masyarakat Universitas Merdeka Malang

Volume 6, No 1, February 2021: 1-9

\section{SIMPULAN DAN SARAN}

\section{Simpulan}

Berdasarkan observasi dan pendampingan yang dilakukan oleh tim pengusul terhadap mitra peserta program, diketahui bahwa 12 guru PAI yang telah mengikuti program pelatihan optimasi platform digital telah mengimplementasikan lebih lanjut input wawasan dan keterampilan yang diperoleh selama pelatihan ke dalam kegiatan pembelajaran PAI di lingkungan pondok pesantren masing-masing. Sejumlah 12 orang guru PAI tersebut telah berupaya mengembangkan media belajar kreatif sesuai hasil pelatihan ketika mengajar secara online selama kebijakan Study from Home (SFH) atau Belajar Dari Rumah (BDR) diberlakukan pada masa pandemik. Tahap berikutnya yang direncanakan oleh tim pengabdian bersama mitra adalah program kegiatan peningkatan kompetensi keterampilan optimasi platform digital yang lebih luas kepada guru non-PAI, sehingga peningkatan kemampuan optimasi digital di lingkungan ponpes menjadi semakin merata. Dari 12 peserta pelatihan dan pendampingan optimasi digital, terdapat pencapaian berupa 12 produk bahan ajar kreatif menggunakan perangkat Google Suites, 12 produk slide kreatif menggunakan PowerPoint, serta peningkatan skor pada pelaksanaan pre-test dan post-test. Hasil tersebut menunjukkan suksesnya kegiatan pengabdian masyarakat yang dilakukan, dan ketercapaian output dari peserta pengabdian yang menunjukkan perkembangan signifikan dalam penguasaan kompetensi optimasi platform digital untuk pembelajaran PAI. Kegiatan pengabdian ini juga sudah diseminasikan dalam prosiding internal lembaga pengusul, yakni Universitas Ahmad Dahlan sebagai salah satu luaran wajib keterlaksanaan program pengabdian.

\section{Saran}

Program ini memiliki keterbatasan di sisi pendanaan, sementara di sisi lain masih banyak guru yang memerlukan pengembangan wawasan terkait kompetensi digital pembelajaran. Untuk itu diperlukan pendampingan dan pendanaan untuk meningkatkan kompetensi pengembangan bahan ajar bagi guruguru mata pelajaran lainnya di lingkungan pondok pesantren.

\section{DAFTAR PUSTAKA}

Jusuf, H. (2016). Penggunaan gamifikasi dalam proses pembelajaran. Jurnal TICOM, 5(1).

Mahmudi, A. (2009). Mengembangkan kompetensi guru melalui lesson study. Jurnal Forum Kependidikan FKIP UNSRI, 28(2).

Nurjanah, I. (2020). Pengaruh penggunaan media Powerpoint terhadap kreativitas mengajar guru pada Mata Pelajaran Pendidikan Agama Islam di Sekolah Menengah Kejuruan Negeri 1 Tembilahan. Asatiza: Jurnal Pendidikan, 1(1), 37-48. https://doi.org/10.46963/asatiza.v1i1.57

Panchenko, D. (2013). The Sherrington-Kirkpatrick Model. Springer Monographs in Mathematics. https://doi.org/10.1007/978-1-4614-6289-7

Pemerintah Indonesia. (2005). Undang-Undang No. 14 Tahun 2005 tentang Guru dan Dosen. Lembaran RI Tahun 2005 No. 14. Jakarta: Sekretariat Negara. 
Optimasi Google Suites dan PowerPoint untuk Membuat Bahan Ajar Kreatif pada Mata Pelajaran PAI

Unik Hanifah Salsabila, Anggi Pratiwi

Rikawati, K., \& Sitinjak, D. (2020). Peningkatan keaktifan belajar siswa dengan penggunaan metode ceramah interaktif. Journal of Educational Chemistry (JEC), 2(2), 40.

https://doi.org/10.21580/jec.2020.2.2.6059

Rushton, S., Juola-Rushton, A., \& Larkin, E. (2009). Neuroscience, play and early childhood education: connections, implications and assessment. Early Childhood Education Journal, 37(5), 351-361. https://doi.org/10.1007/s10643-009-0359-3

Salsabila, U. H. (2019). Membangun kesadaran spiritual di abad 21: Dari aktivitas mengagumi hingga menginspirasi. Journal Al-Manar, 8(1), 51-60.

Salsabila, U. H., Pratiwi, A., \& Ichsan, Y. (2020). Pengarusutamaan literasi spiritual sebagai konstruksi dasar pengembangan sains holistik di ruang kelas. Journal Al-Manar, 9(1), 211-232.

Tim Dosen UAD. (2019). Rencana Strategis Penelitian (RENSTRA) Universitas Ahmad Dahlan. Yogyakarta: Lembaga Penelitian dan Pengabdian kepada Masyarakat Universitas Ahmad Dahlan. Retrieved May 27, 2020, from http://lppm.uad.ac.id/renstra-uad/

Tim Dosen UAD. (2020). Panduan Pengabdian kepada Masyarakat Universitas Ahmad Dahlan. Yogyakarta: Lembaga Penelitian dan Pengabdian kepada Masyarakat Universitas Ahmad Dahlan. Retrieved May 27, 2020, from http://lppm.uad.ac.id/panduan-ppm/

Yazdi, M. (2012). E-learning sebagai media pembelajaran interaktif berbasis teknologi informasi. Jurnal Ilmiah Foristek, 2(1). 